\title{
Correlation between Anemia and Preeclampsia in Universitas Airlangga Hospital in 2017
}

\author{
Haris Rasyid Ridho' ${ }^{\mathbb{D}}$, Muhammad Ilham Aldika Akbar ${ }^{2 *}$, Widati Fatmaningrum ${ }^{3}$, Budi \\ Santoso ${ }^{2}$
}

\begin{abstract}
${ }^{1}$ Faculty of Medicine, Universitas Airlangga, Surabaya, Indonesia.
${ }^{2}$ Department of Obstretics and Gynecology, Faculty of Medicine, Universitas Airlangga/Dr. Soetomo General Hospital, Surabaya, Indonesia.

${ }^{3}$ Department of Public Health and Preventive Medicine, Universitas Airlangga/Dr. Soetomo General Hospital, Surabaya, Indonesia.
\end{abstract}

\section{A B S T R A C T}

Introduction: One of the causes of acute kidney injury that is increasingly soaring is preeclampsia syndrome. Globally, the maternal mortality rate reaches 287,000 per year, and preeclampsia is a major contributor. From East Java Provincial Health Office data, per 100,000 pregnancies, 114 had preeclampsia syndrome. Anemia is one of the highest causes of maternal death, the global prevalence of anemia in pregnant women reaches $55.9 \%$. There have not been many significant studies on the effect of anemia with the incidence of preeclampsia.

Methods: This was observational analytic study with a case and control design which used a chi-square and fisher exact measurement tool. The data samples were patients of pregnant women who had preeclampsia syndrome categorized as cases, and those who did not have preeclampsia were categorized as controls. The data has been obtained from medical records; these include ages, the number of parities, the number of pregnancies, body mass index (BMI), the number of childbirths, types of preeclampsia, and hemoglobin levels. The data has been obtained from the result of the medical record observations that were processed and analyzed in descriptive of statistics which used percentage and cross tab.

Results: The case study group or preeclampsia pregnant women who experienced anemia were 34 patients or $50 \%$ of 68 pregnant women and in the control group were 53 patients or $39 \%$ of anemia patients out of 136 patients. The chi-square statistical test obtained values $(p=0.133)$. The samples needed were 68 case groups and 136 cases as controls.

Conclusion: There was no relationship between anemia and preeclampsia.

\footnotetext{
*Correspondence: Dokter_aldi@yahoo.com
}

JUXTA: Jurnal IImiah Mahasiswa Kedokteran Universitas Airlangga

p-ISSN: 1907-3623; e-ISSN: 2684-9453

DOI: 10.20473/juxta.V12I22021.61-65

Open access under Creative Commons Attribution-ShareAlike 4.0 International License (CC-BY-SA)

\section{ARTICLE INFO}

\author{
Article history: \\ Received 4 March 2021 \\ Received in revised form 8 July \\ 2021
}

Accepted 3 August 2021

Available online 31 August 2021

\section{Keywords:}

Anemia,

Hemoglobin,

Preeclampsia,

Pregnancy. 


\section{Introduction}

Preeclampsia and severe preeclampsia are still serious problems for the health of mothers and newborns. This incident is linked to data on maternal mortality that reaches 50,000-100,000 annually globally. An estimated 287,000 maternal deaths worldwide in 2010 and an average death due to bleeding, hypertension disorders, preeclampsia, and sepsis. ${ }^{1}$

Preeclampsia is a pregnancy-specific syndrome that adversely affects many organ systems. This syndrome is based on the onset of hypertension and proteinuria that occur after 20 weeks of pregnancy. This syndrome has many precipitating factors, such as the age of pregnant women, hypertension, obesity, primigravida, single pregnancy, and anemia. A study reported that women with severe anemia had a risk factor for preeclampsia 3.6 times higher than women without anemia and 17 (17.7\%) of 97 women with severe anemia had pregnancy hypertension or preeclampsia

World Health Organization (WHO) has defined anemia in pregnancy as a hemoglobin $(\mathrm{Hb})$ concentration of less than $11 \mathrm{~g} / \mathrm{dl}$. Mild anemia usually occurs without being characterized by symptoms, but severe anemia cause symptoms such as fatigue, weakness, dizziness, and drowsiness, including loss of normal color on the skin and lips. ${ }^{2}$

Preeclampsia is a multifactorial disease that can indirectly cause organ system abnormalities or physiological abnormalities in pregnant women, such as kidney, nerve, hematological, and liver damage. Preeclampsia that is not treated seriously will have adverse effects on the fetus and the mother and can even cause death from both. ${ }^{3}$ This study was performed because the incidence of preeclampsia and anemia is one of the factors causing the increasing maternal mortality rate.

Based on the background described above, the researchers aim to investigate any significant relation between anemia and the incidence of preeclampsia at Universitas Airlangga hospital.

\section{Methods}

The research design used was a type of observational analytic study that was adjusted to the design of the study, namely case-control.

The data used were medical records of patients of pregnant women in the management system of Airlangga University Hospital from 1 January to 31 December 2017. The inclusion criteria include pregnant women who did not have metabolic syndrome and who had a complete blood test, while the exclusion criteria include uncompleted medical records. The sample data observed the number of pregnant women with decreased hemoglobin levels to less than $11 \mathrm{~g} / \mathrm{dl}$. The data were divided to two groups of pregnant women which include the characteristics of age, number of parities, number of pregnancies, anemia, body mass index (BMI), and type of preeclampsia as stated in the medical record. The data were obtained from the results of medical record observations that were processed and analyzed in descriptive of statistics using percentage cross tab to observe the correlation between anemia and preeclampsia which used Chi-square test.

\section{Results}

Table 1. Characteristics and correlation between risk factor and preeclampsia

\begin{tabular}{|c|c|c|c|c|c|c|}
\hline \multirow[b]{2}{*}{ Age } & & \multicolumn{2}{|c|}{ Control } & \multicolumn{2}{|c|}{ Case } & \multirow[t]{2}{*}{$\mathbf{p}$} \\
\hline & $\begin{array}{l}<20 \text { years old } \\
20-35 \text { years old } \\
>35 \text { years old }\end{array}$ & $\begin{array}{c}\text { Amount } \\
1 \\
111 \\
24\end{array}$ & $\begin{array}{c}\text { Percentage } \\
7 \% \\
81.6 \% \\
17.6 \%\end{array}$ & $\begin{array}{c}\text { Amount } \\
0 \\
55 \\
13\end{array}$ & $\begin{array}{c}\text { Percentage } \\
0 \% \\
80.9 \% \\
19.1 \%\end{array}$ & \\
\hline Number of Parities & $\begin{array}{c}0 \\
1 \\
2 \\
>3 \\
\end{array}$ & $\begin{array}{c}49 \\
49 \\
30 \\
8 \\
\end{array}$ & $\begin{array}{c}36 \% \\
36 \% \\
22.1 \% \\
5.9 \% \\
\end{array}$ & $\begin{array}{c}29 \\
21 \\
14 \\
4 \\
\end{array}$ & $\begin{array}{c}43 \% \\
30.9 \% \\
20.6 \% \\
5.9 \% \\
\end{array}$ & 0.822 \\
\hline Number of Pregnancy & $\begin{array}{c}1 \\
2 \\
3 \\
>3 \\
\end{array}$ & $\begin{array}{l}47 \\
39 \\
35 \\
15 \\
\end{array}$ & $\begin{array}{c}34.6 \% \\
28.7 \% \\
25.7 \% \\
11 \% \\
\end{array}$ & $\begin{array}{c}23 \\
22 \\
15 \\
8 \\
\end{array}$ & $\begin{array}{l}33.8 \% \\
22.1 \% \\
11.8 \% \\
11.8 \% \\
\end{array}$ & 0.922 \\
\hline Body Mass Index & $\begin{array}{c}<18.5 \mathrm{~kg} / \mathrm{m}^{2} \\
18.5-22.99 \mathrm{~kg} / \mathrm{m}^{2} \\
23-24.99 \mathrm{~kg} / \mathrm{m}^{2} \\
\geq 25 \mathrm{~kg} / \mathrm{m}^{2}\end{array}$ & $\begin{array}{c}1 \\
27 \\
32 \\
76\end{array}$ & $\begin{array}{c}7 \% \\
19.9 \% \\
23.5 \% \\
55.9 \% \\
\end{array}$ & $\begin{array}{l}0 \\
0 \\
5 \\
63\end{array}$ & $\begin{array}{c}0 \% \\
0 \% \\
7.4 \% \\
92.6 \% \\
\end{array}$ & 0.00 \\
\hline Number of Childbirth & $\begin{array}{c}\text { Aterm childbirth } 0 \\
\text { Aterm childbirth } 1 \\
\text { Aterm childbirth }>2\end{array}$ & $\begin{array}{l}44 \\
49 \\
43 \\
\end{array}$ & $\begin{array}{c}32.4 \% \\
36 \% \\
31.6 \% \\
\end{array}$ & $\begin{array}{l}24 \\
23 \\
21 \\
\end{array}$ & $\begin{array}{l}35.3 \% \\
33.8 \% \\
30.9 \% \\
\end{array}$ & 0.91 \\
\hline Type of Preeclampsia & $\begin{array}{c}\text { No preeclampsia } \\
\text { Preeclampsia } \\
\text { Severe preeclampsia }\end{array}$ & $\begin{array}{c}136 \\
0 \\
0 \\
\end{array}$ & $\begin{array}{c}100 \% \\
0 \% \\
0 \% \\
\end{array}$ & $\begin{array}{c}0 \\
50 \\
18 \\
\end{array}$ & $\begin{array}{c}0 \% \\
73.5 \% \\
26.5 \% \\
\end{array}$ & 0.00 \\
\hline Anemia & $\begin{array}{c}\text { Anemia } \\
\text { No anemia } \\
\text { Total }\end{array}$ & $\begin{array}{c}53 \\
83 \\
136\end{array}$ & $\begin{array}{c}39 \% \\
61 \% \\
100 \%\end{array}$ & $\begin{array}{l}34 \\
34 \\
68\end{array}$ & $\begin{array}{c}50 \% \\
50 \% \\
100 \%\end{array}$ & 0.133 \\
\hline
\end{tabular}


Based on the highest age group in the group of cases, the vulnerable age was $20-35$ years old. It was stated that there was no significant relationship between the characteristics of age with the incidence of preeclampsia.

There was no significant relationship between the number of children born alive in the case group and the control group. There was no significant relationship between the number of pregnancy rates in the case and the control group.

The highest BMI in the case group was found in BMI $\geq 25 \mathrm{~kg} / \mathrm{m}^{2}$ with $92.6 \%$. In the control group or the group of pregnant women without preeclampsia, the highest percentage was also found in BMI $\geq 25 \mathrm{~kg} / \mathrm{m}^{2}$ with $53.9 \%$. In statistical calculations using fisher exact, it obtained a value of $p=0.00$, which means that there was a significant relationship between $\mathrm{BMI}$ and the incidence of preeclampsia.

In the number of childbirth, the highest percentage in the case group was found at the number of $35.2 \%$. In the control group, the highest number of aterm childbirth were found at the number of $36.0 \%$. In statistical calculations, the value obtained $p=0.910$, which means that there was no significant value between the number of aterm childbirth and the incidence of preeclampsia.

Based on the characteristics of preeclampsia, the highest percentage of cases in mild preeclampsia was $73.5 \%$, while in pregnant women and in severe preeclampsia patients, it was $26.5 \%$. At the same time, the patients' control group were 136 patients or $100 \%$ of a diagnosis of preeclampsia. In statistical calculations using fisher exact, it obtained $p$ value of 0.00 .

The results of the case group or anemia pregnant women with preeclampsia were $50 \%$. The highest control group was found in normal pregnant women without anemia in $61 \%$ of patients. The statistical analysis results used the chi-square method of the two variables, which obtained the value of $p=0.133$, which means that there was no significant correlation between anemia and the incidence of preeclampsia at Universitas Airlangga Hospital, Surabaya.

\section{Discussion}

In the profile of age characteristics, the highest is in the group of cases at vulnerable ages of 20-35 years old by $80.8 \%$ or 55 patients. In the control group, the highest proportion was in the $20-35$ years old of $81.61 \%$ or 111 patients. It can be concluded that the number of pregnant women aged 20-35 years old are more vulnerable than $<20$ years old and $>35$ years old patients. Result analysis using chi-square obtained a p-value of 0.757 , which means no significant relationship was found between age and the incidence of preeclampsia. Women who had a risk of preeclampsia were usually found in women of extreme age, namely teenagers and women aged 35 years old and above. ${ }^{4}$ Patients aged $<20$ years old and $>35$ years old are considered high-risk age disorders. At the age of $>35$ years old, there will be tissue changes and changes in elasticity and flexibility of the birth canal, thus it is possible to inhibit the process of pregnancy and birth. ${ }^{5}$

Based on the age of $<20$ years old, this age can be at high risk of miscarriage, birth disorders, and even death caused by female reproductive organs are not fully ready to receive conception. Based on the number of parity or live birth children, it was divided into parity 0 , parity 1,2 , and more than equal to 3 or multiparity in pregnant women, the case group found the highest number of live births found in parity 0 pregnant women is equal to $42.64 \%$ or as many as 29 patients. In the control group or not, the highest percentage of preeclampsia was found in the number of children born alive, one that is equal to $36.76 \%$ or as many as 50 patients, the results of the analysis of the chi-square test obtained a p-value of 0.822 which means that there was no significant relationship was found between the number of parities with the incidence preeclampsia. This research was inversely related to one of the pathophysiologies of preeclampsia. In the multiparity of the endometrial environment around the implantation area, it cannot be perfect or not ready to accept the conception so that the oxygen supply in the conception results is not good and causes developmental failure. The growth of the conception result is not maximal. This can increase the risk of preeclampsia. A study conducted by Transyah in 2018 examined the relationship between parity and maternal age with preeclampsia incidence.

On the characteristics of the number of pregnancies that are classified into the number of pregnancies 1, 2, 3, and more than 3 , the highest value in the group of preeclampsia pregnant women or case group is the number of pregnancies as many as $33.8 \%$ or 23 patients of pregnant women. In the control group or the group of pregnant women without preeclampsia, the highest value was also found in the number of gestations 1 which was $34.55 \%$ or as many as 47 patients of pregnant women. The results of the analysis of the Chi-Square test obtained a pvalue of 0.922 which means that no significant relationship was found between the number of pregnancies and the incidence of preeclampsia. This research is not by the pathophysiological characteristics of the number of pregnancies that can cause preeclampsia. It can be concluded that pregnant women at risk for preeclampsia, namely pregnant women who have a history of first pregnancy or primigravida, can occur because of the influence of first exposure to colion villus. The formation of HLA-G (Human Leukocyte Antigen), which functions to block antibodies, has not been fully formed so that the process of implantation of the trophoblast into the decidual tissue of the mother becomes disrupted. ${ }^{6}$

Percentage of BMI of pregnant women classified based on Asia Pacific criteria, BMI can be categorized as normal if it is in the range of $18.5-22.99 \mathrm{~kg} / \mathrm{m}^{2}$. BMI values $<18.5 \mathrm{~kg} / \mathrm{m}^{2}$ are categorized as underweight, BMI 23-24.99 $\mathrm{kg} / \mathrm{m}^{2}$, categorized as overweight, and BMI $\geq 25 \mathrm{~kg} / \mathrm{m}^{2}$ are categorized as obese. In the case group of pregnant women with preeclampsia, the highest value is found in BMI more or equal to $\geq 25 \mathrm{~kg} / \mathrm{m}^{2}$ as much as $96.6 \%$ or 63 patients. In the control group or group of pregnant women, the highest percentage of normotension was found in BMI $\geq 25 \mathrm{~kg} / \mathrm{m}^{2}$ as much as $53.6 \%$ or 76 patients from the analysis using fisher exact obtained $p$-value of 0.00 . There is a significant relationship between $\mathrm{BMI}$ and Preeclampsia. Based on the value of BMI divided into 
underweight, overweight obesity can be seen in these data that pregnant women who have preeclampsia are included in the obesity category. Obesity is a trigger factor from the occurrence of many abnormalities in pregnancy; obesity is a condition where the body condition is overweight. Obesity is caused by many factors such as genetic factors, metabolic disorders, and excessive consumption of food. The more weight gain, the more blood will be pumped by the heart throughout the body. ${ }^{7}$

Based on the characteristics of term births classified into the number of term births at 0 , the number of term births at 1 , and the number of term births is more than equal to 2. In the case group or group of pregnant women who experienced preeclampsia, the highest percentage was found in the number of deliveries of $A$ term 0 by $35.2 \%$ or 24 patients. In the control group without preeclampsia, the highest number of term deliveries was $36.0 \%$ or 49 pregnant women, $\mathrm{p}$-value $=0.910$, which means there was no significant relationship between the incidence of preeclampsia and term delivery.

In both groups, between cases and controls, blood hemoglobin levels were analyzed, and anemia was observed. In the case group of preeclampsia, pregnant women who experienced anemia were 34 patients or $50 \%$ of patients from 68 pregnant women and in the control or normotension group, 53 patients were anemic out of 136 patients. Based on the characteristic weight of mild preeclampsia classified as non-preeclampsia, mild preeclampsia and severe preeclampsia were highest in the case group with mild preeclampsia as much as $73.5 \%$ or as many as 50 pregnant patients. Meanwhile, the patient control group was 136 patients or $100 \%$ or not diagnosed with preeclampsia. This research is by the Transyah research conducted at RSUP Dr. M. Djamil Padang reported that 20 pregnant women, or $60.6 \%$ had mild preeclampsia while 13 pregnant women or $39.4 \%$ had severe preeclampsia. The survey at the hospital experienced a significant increase compared to the previous year. ${ }^{8}$ In the analysis of the relationship between the two groups, a p-value of $(0.133)$ was obtained, which means there was no significant relationship between anemia and the incidence of preeclampsia in Universitas Airlangga Hospital, Surabaya.

\section{Analysis of Anemia with Preeclampsia}

Analysis of this research was conducted to look for the relationship of anemia with the incidence of preeclampsia at Universitas Airlangga Hospital, Surabaya. Pregnant women patients who experienced anemia were 34 patients or $50 \%$ of 68 pregnant women and in the control group found 53 or $39 \%$ of anemia patients out of 136 patients, in the chi-square statistical test obtained values $(p=0.133)$. Thus, it can be concluded that this study found no significant relationship between anemia with the incidence of preeclampsia in Airlangga University Hospital.

The unrelatedness of these two variables was reinforced by the relatively high physiological theory of normal pregnancy. This is related to the physiological theory of normal pregnancy. In a healthy pregnancy, the sixth week of plasma volume tends to increase. A disproportionate increase in the red blood cell mass increases because changes in red blood cell mass can cause a reduction in oxygen extraction in the heart vascular. This event causes increased plasma transport even with very low hemoglobin. However, this increase in plasma is an indication of normal fetal growth. ${ }^{9}$ The results of research supported by Elagari, M. In that study, it was reported that hemoglobin $(\mathrm{Hb})$ levels and red blood cell index in the two groups had significant differences. Preeclampsia pregnant women have lower hemoglobin levels compared to normal mothers $(p<0.01)$. On the other hand, RDW, PCV, MCV, $\mathrm{MCH}$, and $\mathrm{MCHC}$ were significantly higher in preeclampsia women compared to normal women $(p<0.01)$. However, the number of red blood cells and reticulocytes between the two groups did not show a significant difference. ${ }^{10}$ In research conducted by Nasiri, et al. who examined the levels of Longitudinal Discriminant Analysis of Hemoglobin Levels to Predict Preeclampsia. The research reported the mean hemoglobin value of preeclampsia of pregnant women with hemoglobin of women without preeclampsia in trimesters one to two and three. with a difference of $0.46 \mathrm{~g} / \mathrm{dl}$ and $(\mathrm{p}=$ 0.003). ${ }^{11}$

\section{Conclusion}

There is no relationship between anemia with the incidence of preeclampsia in Universitas Airlangga Hospital, Surabaya. Although this research did not find a significant relationship between anemic pregnant women with the incidence of preeclampsia, it must be kept in mind that the prevalence of maternal mortality caused by anemia and preeclampsia remains high. Thus, pregnant women are recommended for routine control of pregnancy to the doctor.

\section{CONFLICT OF INTEREST}

The author stated there is no conflict of interest in this study.

\section{REFERENCES}

1. Ngwenya S. Severe Preeclampsia and Eclampsia: Incidence, Complications, and Perinatal Outcomes at a Low-Resource Setting, Mpilo Central Hospital, Bulawayo, Zimbabwe. Int J Womens Health 2017; 9: 353-357.

2. Khaskheli M-N, Baloch S, Sheeba A, et al. Iron Deficiency Anaemia is Still a Major Killer of Pregnant Women. Pakistan J Med Sci 2016; 32: 630-634.

3. Eastabrook G, Brown M, Sargent I. The Origins and EndOrgan Consequence of Pre-Eclampsia. Best Pract Res Clin Obstet Gynaecol 2011; 25: 435-447.

4. Sarmin N. Faktor-faktor yang Berhubungan dengan Kejadian Preeklampsia pada Ibu Bersalin di Ruangan Camar II RSUD Arifin Achmad Provinsi Riau Tahun 2014. J Kesehat Komunitas 2015; 3 : 29. 
5. Sumampouw CM, Tendean HMM, Wagey FW. Gambaran Preeklampsia Berat dan Eklampsia Ditinjau dari Faktor Risiko di RSUP Prof. Dr. RD Kandou Manado. J Med dan Rehabil; 1.

6. Denantika O, Serudji J, Revilla G. Hubungan Status Gravida dan Usia Ibu terhadap Kejadian Preeklampsia di RSUP Dr. M. Djamil Padang Tahun 2012-2013. J Kesehat Andalas; 4.

7. Nursal D, Tamela P, Fitrayeni F. Faktor Risiko Kejadian Preeklampsia pada Ibu Hamil di RSUP Dr. M. Djamil Padang Tahun 2014. J Kesehat Masy Andalas 2017; 10: 38

8. Transyah C. Hubungan Umur dan Paritas Ibu Bersalin dengan Kejadian Pre-Eklampsia. Hum Care J; 3.
Epub ahead of print 2 May 2018. DOI: 10.32883/hcj.v3i1.100.

9. Sifakis S, Pharmakides G. Anemia in Pregnancy. Ann N Y Acad Sci 2000; 900: 125-136.

10. Elgari MM, Khabour OF, Alhag SM. Correlations between Changes in Hematological Indices of Mothers with Preeclampsia and Umbilical Cord Blood of Newborns. Clin Exp Hypertens 2019; 41: 58-61.

11. Nasiri M, Faghihzadeh $\mathrm{S}$, Alavi Majd $\mathrm{H}$, et al. Longitudinal Discriminant Analysis of Hemoglobin Level for Predicting Preeclampsia. Iran Red Crescent Med J 2015; 17: e19489. 